\title{
Nuclear expression of TCF4/TCF7L2 is correlated with poor prognosis in patients with esophageal squamous cell carcinoma
}

Hideyuki Ishiguro*, Takehiro Wakasugi, Yukio Terashita, Nobuhiro Sakamoto, Tatsuya Tanaka, Hiroyuki Sagawa, Tomotaka Okubo and Hiromitsu Takeyama

* Correspondence:

h-ishi@med.nagoya-cu.ac.jp

Department of Gastroenterological

Surgery, Nagoya City University

Graduate School of Medical Science,

1 Kawasumi, Mizuho-cho,

Mizuho-ku, Nagoya 467-8601, Japan

\begin{abstract}
The prognosis for patients with esophageal cancer remains poor. Therefore, the identification of novel target molecules for the treatment of esophageal cancer is necessary. Here, we investigated the clinicopathological significance of transcription factor 4/transcription factor 7-like 2 (TCF4/TCF7L2) in resectable esophageal squamous cell carcinoma (ESCC), because TCF4/TCF7L2 expression has not been studied in esophageal cancer previously.

This study included 79 patients with esophageal cancer who underwent surgery between 1998 and 2005. The expression of the TCF4/TCF7L2 protein in the nucleus of esophageal cancer cells was analyzed using immunohistochemistry. We examined the correlation between TCF4/TCF7L2 expression, clinicopathological factors, and prognosis in patients with ESCC.

TCF4/TCF7L2 was expressed in $57 \%(45 / 79)$ of patients. TCF4/TCF7L2 expression was correlated with T factor (T1 vs. T2-4, $p=0.001$ ), stage (I vs. II-IV, $p=0.0058$ ), Ly factor $(p=0.038)$, and $V$ factor $(p=0.038)$ and did not correlate with age, gender or $\mathrm{N}$ factor. Furthermore, patients who were positive for TCF4/TCF7L2 had a significantly lower survival rate than those who were negative for TCF4/TCF7L2 (log-rank test, $p=0$. 0040). TCF4/TCF7L2 expression significantly affected the survival of patients with ESCC. Positive expression of TCF4/TCF7L2 was correlated with a poor prognosis after a curative operation in patients with ESCC.
\end{abstract}

Keywords: Esophageal cancer, Immunohistochemistry, Prognosis, TCF4/TCF7L2, Wnt signal, Surgery, Clinicopathological factor

\section{Introduction}

The prognosis of patients with esophageal cancer remains poor, emphasizing the need for the development of new treatment strategies. Today, the overall 5-year survival rate is less than $50 \%$, despite the use of multimodal therapies. Even in early-stage disease, many patients develop a local recurrence of tumors or distant metastasis within a short period of time after operation. To develop novel treatment strategies, it is important to understand the biological behavior of esophageal cancer. Recent studies identified several genes and molecules involved in the origin and/or progression of esophageal cancer, including TP53 [1], deleted in esophageal cancer 1 (DEC1) [2], deleted in colorectal cancer (DCC) [3], deleted in lung cancer 1 (DLC1) [4], cyclin D1 [5],

(c) 2016 The Author(s). Open Access This article is distributed under the terms of the Creative Commons Attribution 4.0 International License (http://creativecommons.org/licenses/by/4.0/), which permits unrestricted use, distribution, and reproduction in any medium, provided you give appropriate credit to the original author(s) and the source, provide a link to the Creative Commons license, and indicate if changes were made. The Creative Commons Public Domain Dedication waiver (http://creativecommons.org/ publicdomain/zero/1.0/) applies to the data made available in this article, unless otherwise stated. 
adenomatous polyposis coli (APC) [6], and survivin [7]. However, the precise mechanisms that underlie the development and progression of esophageal squamous cell carcinoma (ESCC) remain unclear.

The Wnt signaling pathway regulates important cellular processes, including development and differentiation, apoptosis, immunologic and inflammatory responses, cellcycle progression and cellular division [8,9]. Transcription factor $4 /$ transcription factor 7-like 2 (TCF4/TCF7L2) is a key molecule of the Wnt signaling pathway, which acts as a transcriptional factor in the nucleus $[8,10]$. Downstream genes of the Wnt signaling pathway include cyclin D1 and c-myc. To the best of our knowledge, no reports have described the clinicopathological significance of TCF4/TCF7L2 protein expression in the progression of various malignancies.

In this study, we investigated the clinicopathological significance of TCF4/TCF7L2 protein expression in 79 patients with resectable ESCC.

\section{Materials and methods}

\section{Tissue samples}

Samples were obtained from 79 patients with ESCC who underwent operation at the Department of Gastroenterological Surgery, Nagoya City University Medical School between 1998 and 2005 without pre-operative chemotherapy or radiation. The tumors were classified according to the guidelines for clinical and pathological studies on carcinoma of the esophagus. The samples were used after obtaining written consent from the patients.

\section{Immunohistochemistry}

Immunohistochemical staining was performed on formalin-fixed, paraffin-embedded primary human ESCC tissues using the monoclonal anti-TCF4 antibody (Cell Signaling, NY) at 1:200. Paraffin-embedded tumor sections were deparaffinized, rehydrated, heattreated by microwaving in $10 \mathrm{mM}$ citrate buffer for $15 \mathrm{~min}$ for antigen retrieval, and cooled to room temperature. The sections were then treated with $0.3 \% \mathrm{H}_{2} \mathrm{O}_{2}$ in methanol for $30 \mathrm{~min}$ to neutralize the endogenous peroxidases, blocked with nonspecific goat serum for $10 \mathrm{~min}$, and incubated with the H-100 antibody overnight at room temperature in a humid chamber. The immunoreactive protein was detected with a DAKO Envision System, HRP (DAB), and sections were counterstained with hematoxylin. Two independent investigators subjectively assessed the immunostaining of TCF4, and discordant results were resolved by consultation with a third investigator. For the evaluation of TCF4 expression, immunostaining was considered positive only when unequivocally strong nuclear staining was present in more than $50 \%$ of the tumor cells, as analyzed using a light microscope. Cases with faint staining only were considered negative.

\section{Statistical analysis}

The chi-squared test was used to analyze the correlations between the clinicopathological factors and the expression of TCF4/TCF7L2. The survival rates were calculated according to the Kaplan-Meier method. Multivariate analysis of Cox's proportional 
hazard risk model was used to obtain the conditional risk of death due to ESCC. Differences were considered statistically significant for $P$ values less than 0.05 .

\section{Results}

\section{Expression of TCF4/TCF7L2 in ESCC}

First, we investigated the expression of the TCF4/TCF7L2 protein in ESCC tissues using immunohistochemistry. Representative images of TCF4/TCF7L2 immunostaining are shown in Fig. 1. Typical ESCC cells showed diffuse nuclear staining for TCF4/ TCF7L2, and the cell membrane and cytoplasm showed little to no staining. There is almost no nuclear staining in normal esophageal mucosa of resected tissue (Fig. 1c). Immunostaining for TCF4/TCF7L2 was positive in $56.9 \%$ (45/79) of patients. TCF4/ TCF7L2 expression correlated significantly with the T factor, p-stage, lymphatic invasion and vein invasion and did not correlate with the $\mathrm{N}$ factor (Table 1).

\section{Survival curves and expression of TCF4/TCF7L2}

Next, we investigated the correlation between immunostaining for TCF4/TCF7L2 and survival of patients with ESCC after surgery. TCF4/TCF7L2 had a significant effect on patient survival (Fig. 2), and patients with positive staining for TCF4/TCF7L2 had significantly shorter survival after surgery than patients with negative staining $(16.7 \pm 1.7$ months $[n=45]$ vs. $30.6 \pm 2.6$ months [ $n=34$ ], respectively; $p=0.004$ by log-rank test; Fig. 2 ).

Univariate analysis showed that, among the clinicopathological factors examined in this study, the extent of primary tumor (risk ratio, 4.184; $p<0.0001$ ), lymph node

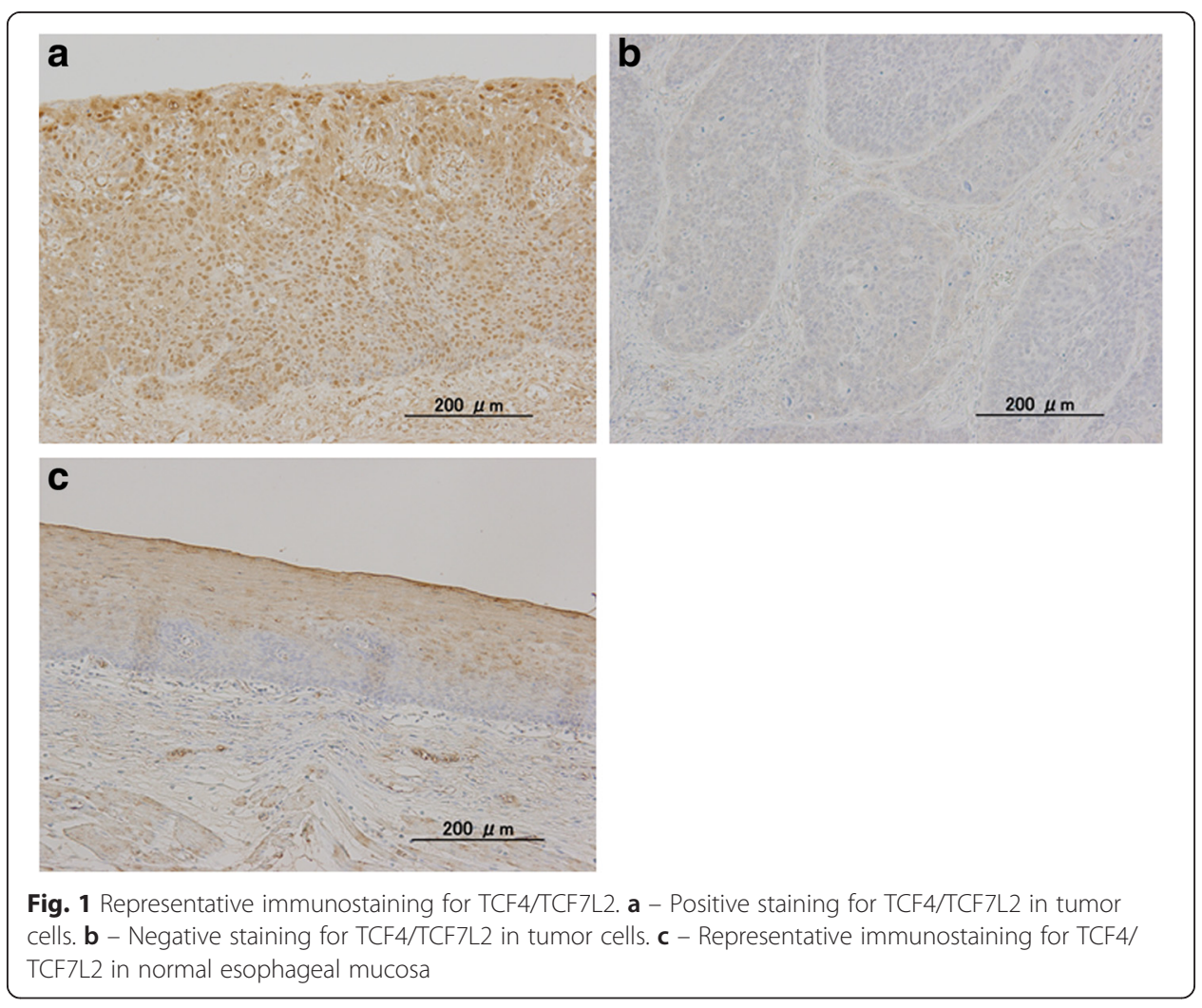


Table 1 Correlation of TCF4 IHC in esophageal cancer with clinicopathological factors, including patient and tumor characteristics

\begin{tabular}{|c|c|c|c|c|}
\hline \multirow[b]{2}{*}{ Characteristics } & \multirow[b]{2}{*}{ Case } & \multicolumn{2}{|c|}{ No. of patients $(n=79)$} & \multirow[b]{2}{*}{$p$-value } \\
\hline & & TCF4(+) & TCF4(-) & \\
\hline \multicolumn{5}{|l|}{ Age at surgery } \\
\hline$<65$ years & 44 & 25 & 19 & \\
\hline$>65$ years & 35 & 20 & 15 & 0.614 \\
\hline \multicolumn{5}{|l|}{ Gender } \\
\hline Male & 63 & 35 & 28 & \\
\hline Female & 16 & 10 & 6 & 0.573 \\
\hline \multicolumn{5}{|l|}{ Tumor status } \\
\hline $\mathrm{T} 1$ & 15 & 3 & 12 & \\
\hline $\mathrm{T} 2$ & 9 & 5 & 4 & \\
\hline T3 & 32 & 19 & 13 & \\
\hline T4 & 22 & 17 & 5 & \\
\hline T1 vs T2-4 & & & & 0.001 \\
\hline \multicolumn{5}{|c|}{ Lymph node status } \\
\hline NO & 18 & 7 & 11 & \\
\hline N1 & 61 & 38 & 23 & \\
\hline No vs N1 & & & & 0.078 \\
\hline \multicolumn{5}{|c|}{ Pathological stage } \\
\hline । & 11 & 2 & 9 & \\
\hline$\|$ & 13 & 9 & 4 & \\
\hline III & 22 & 10 & 13 & \\
\hline IV & 32 & 23 & 9 & \\
\hline I vs ||-IV & & & & 0.0058 \\
\hline \multicolumn{5}{|c|}{ Lymphatic invasion } \\
\hline Negative & 15 & 5 & $5 / 8$ & \\
\hline Positive & 47 & 30 & $22 / 41$ & \\
\hline Unknown & 16 & & & 0.038 \\
\hline \multicolumn{5}{|c|}{ Blood vessel invasion } \\
\hline Negative & 28 & 11 & $13 / 21$ & \\
\hline Positive & 34 & 24 & $14 / 28$ & \\
\hline Unknown & 7 & & & 0.038 \\
\hline
\end{tabular}

metastasis (risk ratio, 4.149; $p<0.0001$ ), lymphatic invasion (risk ratio, 6.622; $p=0.003$ ), vein invasion (risk ratio, 2.816; $p=0.0003$ ), and immunostaining for TCF4/TCF7L2 (risk ratio, 2.506; $p=0.0049$ ) were statistically significant prognostic factors. Multivariate analysis revealed that TCF4/TCF7L2 expression was not an independent prognostic factor (data not shown).

\section{Discussion}

The Wnt signaling pathway plays important roles in axis formation during early vertebrate development [11]. Upon Wnt signaling, the phosphorylation of beta-catenin is suppressed through undefined mechanisms, and beta-catenin functions as a transcriptional regulator in the nucleus together with TCF4/LEF1 [12, 13]. A number of 


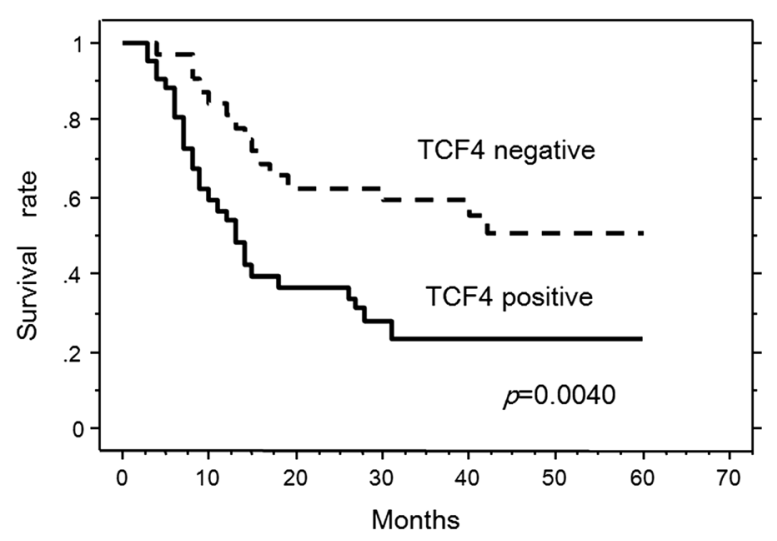

Fig. 2 Kaplan-Meier survival curve for esophageal cancer patients, classified as either positive or negative for TCF4/TCF7L2 immunostaining. TCF4/TCF7L2 status is strongly associated (log-rank, $p=0.0040$ ) with patient survival

downstream genes, such as c-myc [12], cyclin D1 [14, 15], c-jun, fra-1, uPAR, ZO-1 [16], and novel protein band 4.1 like 4 (NBL4) [17] have been reported; however, the precise regulatory mechanisms remain to be resolved. Alterations of APC, AXIN, or betacatenin itself, lead to the accumulation of beta-catenin in the cytoplasm and/or nucleus, resulting in the unregulated transcription of downstream genes [12-14, 16-18]. However, in esophageal cancer cells, the frequency of beta-catenin accumulation in the nucleus is lower than in colon and liver cancer [19]

TCF4/TCF7L2 is a major component of the Wnt signaling pathway. However, because few reports have described the mechanisms mediating Wnt signaling activation in ESCC, the factors that regulate TCF4/TCF7L2 expression in this type of cancer are not known.

In many cancer cells, TCF4/TCF7L2 is localized to the nucleus [20]. Consistent with this observation, our current experiments show that TCF4/TCF7L2 is also expressed in the nucleus of ESCC cells (Fig. 1). In colon cancer cells, TCF4/TCF7L2 is located in the nucleus with beta-catenin [20]. By contrast, for esophageal squamous cancer cells, our data suggest that TCF4/TCF7L2 alone is located in the nucleus without beta-catenin, because beta-catenin is not detected in the nucleus in ESCC [19]. However, the mechanisms that regulate TCF4/TCF7L2 expression in ESCC remain unclear.

There are a few reports that the Wnt signaling pathway is activated in ESCC. Cyclin D1, a downstream gene of the Wnt signaling pathway, is highly expressed in ESCC [21, 22]. Other mechanisms of translocation to the nucleus for TCF4/ TCF7L2 may exist. Downstream genes of the Wnt signal pathway in esophageal cancer may be activated by TCF4/TCF7L2 activation.

Because TCF4/TCF7L2 plays a role in cancer proliferation, additional studies are necessary to determine whether TCF4/TCF7L2 contributes to the growth of esophageal cancers. In our study, TCF4/TCF7L2 was correlated with the T factor of patients with ESCC (Table 1).

Interestingly, we found that TCF4/TCF7L2 predicted the prognosis of patients with ESCC. Therefore, our data suggest that TCF4/TCF7L2 is involved in the cell proliferation of esophageal carcinoma and that TCF4/TCF7L2 is a useful biomarker for predicting prognosis in patients with ESCC. 
Several clinical studies have reported that TCF4/TCF7L2 is an indicator of poor prognosis or malignant potential in hepatocellular carcinomas [17] and colon cancer [11]. The current study may be the first report demonstrating that TCF4/ TCF7L2 is correlated with the prognosis of patients with esophageal squamous cell carcinoma.

In this study, we found that increased expression of TCF4/TCF7L2 in the nucleus of cancer tissue cells was accompanied by the local progression of esophageal cancer (Fig. 1 and Table 2). In addition, patients with high nuclear expression of TCF4/ TCF7L2 had a poorer prognosis (Fig. 2).

Additionally, whether TCF4/TCF7L2 expression is mediated by other mechanisms will be the focus of future studies.

In patients with esophageal cancer, many prognostic markers, including cyclin D1, Ecadherin, and MDM2, have been reported [21, 23]. Furthermore, we also reported that pituitary tumor transforming gene 1 (PTTG1) [24], DNA fragmentation factor 45 (DFF45) [25], NOTCH1 [15], VEGF-C [16], and DROSHA [26] may be prognostic markers of ESCC. Therefore, TCF4/TCF7L2 represents an additional potential prognostic indicator for patients with ESCC.

Although the precise molecular mechanisms through which TCF4/TCF7L2 is activated must be clarified, our data clearly indicate that TCF4/TCF7L2 may be a molecular target for the development of effective therapeutic agents for patients with esophageal cancer.

Table 2 Univariate analysis

\begin{tabular}{|c|c|c|c|}
\hline Parameter & Risk ratio & $95 \% \mathrm{Cl}$ & $p$-value \\
\hline \multicolumn{4}{|c|}{ Age at surgery } \\
\hline$<65$ years & 1 & & \\
\hline$>65$ years & 1.033 & $0.675-1.580$ & 0.8814 \\
\hline \multicolumn{4}{|l|}{ Gender } \\
\hline Female & 1 & & \\
\hline Male & 1.057 & $0.628-1.777$ & 0.8353 \\
\hline \multicolumn{4}{|c|}{ Primary tumor } \\
\hline $\mathrm{T} 1-3$ & 1 & & \\
\hline $\mathrm{T} 4$ & 4.184 & $2.610-6.711$ & $<0.0001$ \\
\hline \multicolumn{4}{|c|}{ Lymph node metastasis } \\
\hline No & 1 & & \\
\hline N1 & 4.149 & $2.242-7.692$ & $<0.0001$ \\
\hline \multicolumn{4}{|c|}{ Lymphatic invasion } \\
\hline Negative & 1 & & \\
\hline Positive & 6.622 & $2.398-18.18$ & 0.003 \\
\hline \multicolumn{4}{|l|}{ Vein invasion } \\
\hline Negative & 1 & & \\
\hline Positive & 2.816 & $1.597-4.975$ & 0.0003 \\
\hline \multicolumn{4}{|c|}{ Immunostaining for TCF4 } \\
\hline negative & 1 & & \\
\hline positive & 2.506 & $1.321-4.739$ & 0.0049 \\
\hline
\end{tabular}




\section{Abbreviations}

APC, adenomatous polyposis coli, DCC, deleted in colorectal cancer, DEC1, deleted in esophageal cancer 1, DFF45, DNA fragmentation factor 45, DLC1, deleted in lung cancer 1, ESCC, esophageal squamous cell carcinoma, NBL4, novel protein band 4.1 like 4, PTTG1, pituitary tumor transforming gene 1, TCF4/TCF7L2, transcription factor 4/transcription factor 7-like 2

\section{Acknowledgments}

The authors would like to thank Ms. Seiko Inumaru for her excellent technical assistance.

\section{Availability of data and materials}

The authors state that the data and materials can be available

\section{Authors' contributions}

HI; leader of this research, immunostainig, statistics. TW; Patients' characterization. YT; Patients' characterization. NS; Obserber of immunostainig. TT; Obserber of immunostainig. HS; Patients' characterization. TO; immunostaing. HT; Proofreading of this paper. All authors read and approved the final manuscript.

\section{Competing interests}

The authors have no proprietary or commercial interest in any product mentioned or concept discussed in this article.

\section{Ethics approval and consent to participate}

The authors declare that they have the approval codes, No.71 obtained from the corresponding ethical committee on human research of our institute.

Received: 30 October 2015 Accepted: 7 December 2015

Published online: 28 July 2016

\section{References}

1. Robert V, Michel P, Flaman JM, Chiron A, Martin C, Charbonnier F, Paillot B, Frebourg T. High frequency in esophageal cancers of p53 alterations inactivating the regulation of genes involved in cell cycle and apoptosis. Carcinogenesis. 2000;21(4):563-5.

2. Nishiwaki T, Daigo Y, Kawasoe T, Nakamura Y. Isolation and mutational analysis of a novel human cDNA, DEC (deleted in esophageal cancer 1), derived from the tumor suppressor locus in 9q32. Genes Chromosomes Cancer. 2000;27(2):169-76.

3. Miyake S, Nagai K, Yoshino K, Oto M, Endo M, Yuasa Y. Point mutations and allelic deletion of tumor suppressor gene DCC in human esophageal squamous cell carcinomas and their relation to metastasis. Cancer Res. 1994; 54(11):3007-10.

4. Daigo Y, Nishiwaki T, Kawasoe T, Tamari M, Tsuchiya E, Nakamura Y. Molecular cloning of a candidate tumor suppressor gene, DLC1, from chromosome 3p21.3. Cancer Res. 1999;59(8):1966-72.

5. Jiang W, Zhang YJ, Kahn SM, Hollstein MC, Santella RM, Lu SH, Harris CC, Montesano R, Weinstein IB. Altered expression of the cyclin D1 and retinoblastoma genes in human esophageal cancer. Proc Natl Acad Sci U S A. 1993;90(19):9026-30

6. Boynton RF, Blount PL, Yin J, Brown VL, Huang Y, Tong Y, McDaniel T, Newkirk C, Resau JH, Raskind WH, et al. Loss of heterozygosity involving the APC and MCC genetic loci occurs in the majority of human esophageal cancers Proc Natl Acad Sci U S A. 1992;89(8):3385-8.

7. Kato J, Kuwabara Y, Mitani M, Shinoda N, Sato A, Toyama T, Mitsui A, Nishiwaki T, Moriyama S, Kudo J, et al. Expression of survivin in esophageal cancer: correlation with the prognosis and response to chemotherapy. Int J Cancer. 2001;95(2):92-5.

8. Duval A, Busson-Leconiat M, Berger R, Hamelin R. Assignment of the TCF-4 gene (TCF7L2) to human chromosome band 10q25.3. Cytogenet Cell Genet. 2000:88(3-4):264-5.

9. Ishiguro H, Tsunoda T, Tanaka T, Fujii Y, Nakamura Y, Furukawa Y. Identification of AXUD1, a novel human gene induced by AXIN1 and its reduced expression in human carcinomas of the lung, liver, colon and kidney. Oncogene. 2001;20(36):5062-6.

10. Saadeddin A, Babaei-Jadidi R, Spencer-Dene B, Nateri AS. The links between transcription, beta-catenin/JNK signaling, and carcinogenesis. Mol Cancer Res. 2009;7(8):1189-96.

11. McMahon AP, Moon RT. Ectopic expression of the proto-oncogene int-1 in Xenopus embryos leads to duplication of the embryonic axis. Cell. 1989;58(6):1075-84

12. He TC, Sparks AB, Rago C, Hermeking H, Zawel L, da Costa LT, Morin PJ, Vogelstein B, Kinzler KW. Identification of c-MYC as a target of the APC pathway. Science. 1998;281(5382):1509-12.

13. Morin PJ, Sparks AB, Korinek V, Barker N, Clevers H, Vogelstein B, Kinzler KW. Activation of beta-catenin-Tcf signaling in colon cancer by mutations in beta-catenin or APC. Science. 1997:275(5307):1787-90.

14. Shtutman M, Zhurinsky J, Simcha I, Albanese C, D'Amico M, Pestell R, Ben-Ze'ev A. The cyclin D1 gene is a target of the beta-catenin/LEF-1 pathway. Proc Natl Acad Sci U S A. 1999;96(10):5522-7.

15. Tetsu O, McCormick F. Beta-catenin regulates expression of cyclin D1 in colon carcinoma cells. Nature. 1999; 398(6726):422-6.

16. Mann B, Gelos M, Siedow A, Hanski ML, Gratchev A, llyas M, Bodmer WF, Moyer MP, Riecken EO, Buhr HJ, et al. Target genes of beta-catenin-T cell-factor/lymphoid-enhancer-factor signaling in human colorectal carcinomas. Proc Natl Acad Sci U S A. 1999;96(4):1603-8.

17. Ishiguro H, Furukawa Y, Daigo Y, Miyoshi Y, Nagasawa Y, Nishiwaki T, Kawasoe T, Fujita M, Satoh S, Miwa N, et al. Isolation and characterization of human NBL4, a gene involved in the beta-catenin/tcf signaling pathway. Jpn J Cancer Res. 2000;91(6):597-603. 
18. Brabletz T, Jung A, Dag S, Hlubek F, Kirchner T. beta-catenin regulates the expression of the matrix metalloproteinase-7 in human colorectal cancer. Am J Pathol. 1999;155(4):1033-8.

19. Kudo J, Nishiwaki T, Haruki N, Ishiguro H, Shibata Y, Terashita Y, Sugiura H, Shinoda N, Kimura M, Kuwabara Y, et al. Aberrant nuclear localization of beta-catenin without genetic alterations in beta-catenin or Axin genes in esophageal cancer. World J Surg Oncol. 2007;5:21.

20. Mulholland DJ, Read JT, Rennie PS, Cox ME, Nelson CC. Functional localization and competition between the androgen receptor and T-cell factor for nuclear beta-catenin: a means for inhibition of the Tcf signaling axis. Oncogene. 2003;22(36):5602-13.

21. Itami A, Shimada Y, Watanabe G, Imamura M. Prognostic value of p27(Kip1) and CyclinD1 expression in esophageal cancer. Oncology. 1999;57(4):311-7.

22. Wu MY, Zhuang CX, Yang HX, Liang YR. Expression of Egr-1, c-fos and cyclin D1 in esophageal cancer and its precursors: An immunohistochemical and in situ hybridization study. World J Gastroenterol. 2004;10(4):476-80

23. Shimada Y, Imamura M, Shibagaki I, Tanaka H, Miyahara T, Kato M, Ishizaki K. Genetic alterations in patients with esophageal cancer with short- and long-term survival rates after curative esophagectomy. Ann Surg. 1997;226(2): 162-8.

24. Shibata Y, Haruki N, Kuwabara Y, Nishiwaki T, Kato J, Shinoda N, Sato A, Kimura M, Koyama H, Toyama T, et al. Expression of PTTG (pituitary tumor transforming gene) in esophageal cancer. Jpn J Clin Oncol. 2002;32(7):233-7.

25. Konishi S, Ishiguro H, Shibata Y, Kudo J, Terashita Y, Sugiura H, Koyama H, Kimura M, Sato A, Shinoda N, et al. Decreased expression of DFF45/ICAD is correlated with a poor prognosis in patients with esophageal carcinoma. Cancer. 2002;95(12):2473-8.

26. Sugito N, Ishiguro H, Kuwabara Y, Kimura M, Mitsui A, Kurehara H, Ando T, Mori R, Takashima N, Ogawa R, et al. RNASEN regulates cell proliferation and affects survival in esophageal cancer patients. Clin Cancer Res. 2006;12(24): $7322-8$.

\section{Submit your next manuscript to BioMed Central and we will help you at every step:}

- We accept pre-submission inquiries

- Our selector tool helps you to find the most relevant journal

- We provide round the clock customer support

- Convenient online submission

- Thorough peer review

- Inclusion in PubMed and all major indexing services

- Maximum visibility for your research

Submit your manuscript at www.biomedcentral.com/submit 